\title{
Naming System of Baduy Tribe
}

\author{
Cece Sobarna ${ }^{1}$, Asri Soraya Afsari ${ }^{2}$, and Santy Yulianti ${ }^{3}$ \\ \{cece@unpad.ac.id\}
}

Fakultas Ilmu Budaya, Universitas Padjajaran ${ }^{12}$, Badan Pengembangan dan Pembinaan Bahasa ${ }^{3}$

\begin{abstract}
Name characterizes a person, place, object, without having trouble in describing it. We can imagine how difficult for us to call someone or say something considering how many people and kinds of things in this world. Therefore, there are efforts in naming system through conventions of each society. The Baduy community in the Banten region, Indonesia has a unique naming system. The name of a child is related to his/her parent. This study aims to describe the naming system in the Baduy community that has been going on so far and to examine the dynamics of its changes. Data collection methods include in-depth interviews (open-ended interviews) and observations, both participatory and periodic observations in the field, and the written document study method. The results show that the names for women are taken from the component of the father's name, whereas the names for boys are taken from the component of the mother's name. Indeed, not all Baduy names follow this pattern. There are also names that do not take component from the name of the father/mother due to their beliefs. For example, many Baduy women named Runtah which means 'trash/waste'. They believe that Runtah name is an enchantment in order for the child would not get sick easily. There also parents' names belong to their children with additional surename like Ambu for mother and Ayah for Father.
\end{abstract}

Keywords: naming system, proper name, Baduy society

\section{Introduction}

Giving a name to someone or something is a universal symptom that exists in every society. We can imagine how difficult it is for us to call someone or say something considering how many people and kinds of things in this world. However, humans give meaning to every name. Name giving something related to the thinking pattern of a society and is a universal symptom (Sobarna, 1993)[1]. Name is a word or phrase that identifies a specific person, animal, place or thing. The name is also a label for someone or something. Most people know only one naming system.

However, Lawson said that in reality this naming system differs in each nation [2, p. 169]. Ainiala et.al [3] describe a name with two fundamental meanings. Name is a combination of words such as Earo (Balitc Sea) referring to certain people, humans, objects, which can be replaced by the terms proper name or proper noun. In addition, a name can also be a reference to someone, or something called an appellative. Onomastics, which is a special linguistic science, discusses proper noun. The history of names will always vary in each language and culture. 
For example, naming in German as it described Rosa and Volker Kohlheim in The Oxford Handbook of Names and Naming [4]. German has a naming system similar to that of the IndoEuropean system. The Germans used a single name until the 12th century which mostly meant war, victory, and glory, such as Lud-wig 'famous-war [rior]', Sieg-mund 'victory -protector '. In addition, names with strong meanings, like beasts such as: Bern-hard, Wolf-hard 'strong like a bear/wolf'. After the 12th century, the Germans stopped using this system. They prefer dynastic names, such as Heinrich and Konrad. At the end of the 15th century, the Germans began to use a family name/last name which can be classified into (1) the father's name, such as Peter, hence the derivation of the Petersen/Peterson (-sen/-son), (2) tribe, as Bayer is derived from Bavarian, BÖhm who comes from Bohemian, (3) origin, such as Bach/Bacher/Bachmann (means: current) because they live/come from the coastal area, (4) occupation /expertise, such as Müller 'miller' (miner), Schmidt ' blacksmith '(blacksmith), Schneider' tailor '(tailor), and (5) individual special characteristics, such as Kraus (curly/curly), Grimm (furious/gri /spooky), Stolz (proud).

Ellen S. Bramwell [4] also states that personal names can be related to anthropology as a culture-influenced name system. Anthropologically, the study of names is always related to how the name is positioned in society, by whom the name is carried, and what is the benefit for their society. This has a strong bearing on name grouping for people. Apart from personal/personal names, these names become a form of classification, such as kinship groupings, surnames and patrilineal surnames, or even wider clans/tribes. The name also provides information about occupation, origins, or even ancestry that can be embedded in the name. The name system used in the community can include both official and unofficial elements. An official name is a name that is recorded and endorsed by the state or other authority, whereas an informal name is usually preserved in the oral tradition.

Bramwell cites Dickinson's (2007) discussion of the Ukrainian village. The practice of official private naming is closely tied to Soviet influence and power. They operate within the official domain and consist of standard Ukrainian first names, patronymic/patriarchal names and official last names. The names exist in a diglossic relationship with unofficial names, which are only used within the community. Locals use a dialect version of the standard Ukrainian name and surname, in addition to alternative first names, locative names, occupational terms, and even terms related to property such as certain cars or horses. This obscure classification of names exists in the ethnographically analyzed tradition of name categorization. Bramwell notes that Dickinson suggested one of the potential functions of the diglossic system was to signify insiders and outsiders through the use of local or official names.

Some of the writings of the naming system in Indonesia can be seen in Widodo [5] dan Kosasih [6]. Widodo [5] writes about the construction of Javanese names in Surakarta. Widodo conclude that the construction of names based on syllables in Javanese is important to determine the position of each part in a name element. Does a syllable (wanda) have the position of an independent morpheme (Su-, Wi-, -ji, -nem, -kem) which should be meaningful, or is it just part of an independent morpheme where each part have no meaning.

The meaning of a name can be started from the results of the description of the name both syllables and elements because the meaning is composed by the elements or components in it. Kosasih [6] writes about the cosmology of the Sundanese self-name system with the conclusion (1) diachronic, there is a tendency that there has been a change in the Sundanese self-name system which can be seen from the development of elements which also affect in the development of its structures. (2) Such development is closely related to (a) the increasing dynamics of society, (b) the development of human language vocabulary as a result of civilization communication, (c) the development of mind (intellect) and human mindset, (d) the development of attitudes, mental, and cultural responses, (e) the development of human needs, 
and what cannot be forgotten is (f) science and technology services through its results. Psychological symptoms that can be felt are, a teenager who feels ashamed of his name, often changes it himself at least to a nickname that is adjusted to modernity or the prevailing name trend. Conversely, a child will feel proud to have a modern name.

Baduy tribe or also called the Kanekes people are the object of endless research which is discussed with various points of view. One of them is R. Cecep Eka Permana, a lecturer in anthropology at the University of Indonesia and also an observer of the Baduy Tribe, in his book Tata Ruang Masyarakat Baduy (Spacial Layout of Baduy) [7] and Kearifan Lokal Masyarakat Baduy Dalam Mitigasi Bencana (Local Wisdom of Baduy in Natural Disaster Mitigation) [8] discussing in depth about the Baduy from an anthropological perspective. Permana discusses in his two books the origin of the name Baduy and the linguistic aspects of the Baduy community.

The term Baduy was given by people outside Baduy and later used by the first ethnographic reports of the composition of the Dutch people. In these reports, the Dutch called it Badoe'i, badoei, or Badoewi (Hoevell 1845, Jacob and Meijer 1891, Pleyte 1909, in Permana, 2006, p. 21)[7]. Then reinforced by the term Baduy in KTP (Kartu Tanda Penduduk) in 1980 which was not rejected by them. While the Baduy themselves call themselves urang Kanekes. They used to call themselves by the name of the area they lived in, such as urang Cibeo, urang Tangtu (Inner Baduy), and urang Panamping (Outer Baduy). The term Baduy has a diverse history. Spanoghe (in Permana 2006 and 2010) [7], [8] states that the name Baduy can come from the word Buddha or also come from the name of the Cibaduy river which flows near this community settlement. The term Baduy arises from a hill called Mount Baduy, and a small river flows nearby, called the Cibaduy River. Some opinions say that the people in this area are actually called urang Baduy, because the Baduy area is the gateway to this area.

Some writings related to names in Sundanese people in general and Baduy in particular are still very limited, such as Danasasmita and Djatisunda [9] and Sobarna [1]. Danasasmita and Djatisunda examined the names of the Kanekes (Baduy) community in relation to the discussion on the life of the Kanekes people, while Sobarna studied names in the Sundanese community as a reflection of their way of thinking. Sobarna's essay is part of a book Makna Nama dalam Bahasa Nusantara: Sebuah Kajian Antropologi (Meanings of Names in Nusantara Language: An Anthropological Study) with editors Robert Sibarani and Henry Guntur Tarigan.

This book presents the subtleties of naming in several Indonesian societies, including Sundanese, Batak, Minangkabau, and Dayak.The Baduy community, in terms of name giving, is the Baduy community which is unique. The Baduy community as indigenous people [10, $\mathrm{p}$. iii] have attractiveness, both in terms of culture and nature. Therefore, it is not surprising that many people come to this place every day with various needs, both formal and informal. Thus, there will be intense and massive interactions with outsiders of different backgrounds, be it social, cultural, or economic. This study aims to describe the naming system of the Baduy community that has been going on so far, to examine the dynamics of changes that have occurred in the naming of the Baduy community.

\section{Research Methods}

Qualitative research as presented by Creswell [11] uses open instruments for in-depth interviews, supporting data, and interpretation. This study collected data through the interview stage and collected names from the family card in the village apparatus. The data analysis uses Sudaryat et.al.[12] and Djajasudarma [13] for the prefixes of Sundanesse Grammar. Interviews 
were conducted to determine the background of the selection of personal names by the Baduy tribe.

The names obtained came from the outer Baduy village of 10 villages, namely Balingbing, Batara, Cicatang I, Cikadu Babakan, Cikopeng, Ciranji Pasir, Cisadane, Gajeboh, Kadu Kohak, Kaduketug I, with a total of 1390 names of children. The names obtained were grouped based on age, gender, and names of parents (father / mother). The classification results were analyzed based on the similarity of the prefixes, the names of the parents starting with the Ayah/Ambu, and the philosophy behind the names Runtah and Pulung.

\section{Results and Discussion}

The Baduy tribe only has a single name (singular name) with a cross structures, where girls 'names have part of the father's name and boys' names have part of the mother's name. There are several structures that can be classified from the names of the Baduy people obtained from several Baduy's respondents.

\section{The prefix of the first syllable in the name of the father/mother}

The Baduy tribe having uniqueness in naming their children. Daughters in a family will take on the same initial syllable /letter characteristics as their father. Likewise, boys will take the same initial syllable / letter characteristics as mothers.

\section{Table 1.}

\begin{tabular}{|c|c|c|c|}
\hline No. & $\begin{array}{l}\text { Name of } \\
\text { Children }\end{array}$ & $\begin{array}{c}\text { Parent Name } \\
\text { (Father/Mother) }\end{array}$ & $\begin{array}{c}\text { Children } \\
\text { Classification }\end{array}$ \\
\hline 1. & Arman & Arba & M.11-25 tahun \\
\hline 2. & Arsan & Arba & M. 26-45 tahun \\
\hline 3. & Arsad & Arba & M. 46-100 tahun \\
\hline 4. & Asman & Asbah & M. 26-45 tahun \\
\hline 5. & Asdi & Asbah & M. 46-100 tahun \\
\hline 6. & Carip & Carsah & M. 0-11 tahun \\
\hline 7. & Caikin & Caiah & M. 46-100 tahun \\
\hline 8. & Edi & Elas & M.11-25 tahun \\
\hline 9. & Jama & Jani & M. 0-11 tahun \\
\hline 10. & Jama & Jani & M.11-25 tahun \\
\hline 11. & Mista & Misnah & M. 0-11 tahun \\
\hline 12. & Ralim & Ramin & M. 0-11 tahun \\
\hline 13. & Sumanta & Sumaah & M. 0-11 tahun \\
\hline 14. & Jamah & Jakim & F. $12-25$ tahun \\
\hline 15. & Jani & Jakim & F. 12-25 tahun \\
\hline 16. & Janah & Jakim & F. 26-45 tahun \\
\hline 17. & Jarpah & Jarman & F. 26-45 tahun \\
\hline 18. & Jarmi & Jarmin & F. 26-45 tahun \\
\hline
\end{tabular}




\begin{tabular}{|r|c|c|c|}
\hline $\mathbf{1 9}$ & Emah & Emod & F. 0-11 tahun \\
\hline $\mathbf{2 0 .}$ & Narti & Narja & F. 0-11 tahun \\
\hline $\mathbf{2 1 .}$ & Narisah & Narja & F. 12-25 tahun \\
\hline $\mathbf{2 2 .}$ & Rani & Ramin & F. 12-25 tahun \\
\hline $\mathbf{2 3 .}$ & Rawi & Ramin & F.46-100 tahun \\
\hline $\mathbf{2 4 .}$ & Rani & Ramin & F.46-100 tahun \\
\hline $\mathbf{2 5}$ & Sani & Sadi & F. 12-25 tahun \\
\hline $\mathbf{2 6 .}$ & Salinah & Salim & F. 12-25 tahun \\
\hline $\mathbf{2 7}$ & Sari & Salim & F. 26-45 tahun \\
\hline
\end{tabular}

Table 1 is representative of classified data. Table 1 shows that each mother's name begins with the syllable Ar- on Arba, Ca- on Carsih, E- on Elas, Ja- on Jani, Mis- on Misnah, Ra- on Ramin, and Su- on Sumaah, then Boys' names will begin with the exact fragment of the mother's name, such as Ar-man, Ar-san, Ca-rip, Ca-ikin, E-di, Ja-ma, Mis-ta, Ra-lim, and Su-manta. This pattern is found in all age groups of children. Likewise with the name of a daughter who takes her father's first syllable, such as Ja-mah from Ja-kim, E-mah from E-mod, Nar-ti from Nar-ja, $R a$-wi from Ra-min, Sa-ni. from Sa-di, and Sa-linah from Sa-lim. This pattern is found in all age groups of children. Parents still use this pattern to name their children. For example, Ramin as the father name, then all the daugthers name are Rani and Rawi. The uniqueness of the name Ramin in the Baduy tribe can be used for men or women.

\section{Ambu and Ayah in the name of their parents}

The Baduy often use the word Ambu in the mother's name, which means mother. Like Ambu Adim, which shows that he is the mother of Adim (son). Likewise, the use of the word Ayah in the name of the father which indicates ownership, such as Ayah Jakiin, the father of Jakiin (son). This naming is not attached to the pattern of names of sons from mothers or names of daughters of fathers.

Table. 2

\begin{tabular}{|c|c|c|c|}
\hline No. & $\begin{array}{c}\text { Name of } \\
\text { Children }\end{array}$ & $\begin{array}{c}\text { Parent Name } \\
\text { (Father/Mother) }\end{array}$ & $\begin{array}{c}\text { Children } \\
\text { Classification }\end{array}$ \\
\hline $\mathbf{2 8}$. & Ramin & Ambu/Ayah Ramin & M. 46-100 tahun \\
\hline $\mathbf{2 9}$ & Arkati & Ambu/Ayah Arkati & F.46-100 tahun \\
\hline $\mathbf{3 0 .}$ & Raman & Ambu/Ayah Raman & M. 26-45 tahun \\
\hline $\mathbf{3 1 .}$ & Rasidah & Ambu/Ayah Rasidah & M. 26-45 tahun \\
\hline $\mathbf{3 2}$. & Arji & Ambu/Ayah Arji & M. 46-100 tahun \\
\hline $\mathbf{3 3 .}$ & Acin & Ambu/Ayah Acin & M. 46-100 tahun \\
\hline $\mathbf{3 4}$ & Yaceu & Ambu/Ayah Yaceu & F. 46-100 tahun \\
\hline $\mathbf{3 5}$ & Pulung & Ambu/Ayah Pulung & M. 46-100 tahun \\
\hline $\mathbf{3 6 .}$ & Pulung & Ambu/Ayah Pulung & M. 12-25 tahun \\
\hline $\mathbf{3 7 .}$ & Asih & Ambu/Ayah Asih & F. 26-45 tahun \\
\hline
\end{tabular}




\begin{tabular}{|c|c|c|c|}
\hline $\mathbf{3 8}$. & Dursah & Ambu/Ayah Dursah & F.46-100 tahun \\
\hline $\mathbf{3 9}$ & Tinggal & Ambu/Ayah Tinggal & M. 12-25 tahun \\
\hline $\mathbf{4 0 .}$ & Darda & Ambu/Ayah Darda & M. 26-45 tahun \\
\hline $\mathbf{4 1 .}$ & Arsah & Ambu/Ayah Arsah & F. 12-25 tahun \\
\hline $\mathbf{4 2 .}$ & Sastim & Ambu/Ayah Sastim & M. 46-100 tahun \\
\hline $\mathbf{4 3 .}$ & Taciwin & Ambu/Ayah Taciwin & M. 46-100 tahun \\
\hline $\mathbf{4 4 .}$ & Sarba & Ambu/Ayah Sarba & M. 46-100 tahun \\
\hline $\mathbf{4 5 .}$ & Karniti & Ambu/Ayah Karniti & F. 46-100 tahun \\
\hline
\end{tabular}

Table 2 shows that the name of the parent starts with the father and is followed by the child's name ( $\mathrm{x}$ ), where $\mathrm{x}$ is the first child, either boy or girl. Likewise, the name of the parent starting with Ambu and followed by the child's name (x), where $\mathrm{x}$ is the first child, either boy or girl. This evidence can be traced to their Family Card records. This conception is found in the age group of children 11-25 years, 26-45 years, and 46-100 years.

For example, Ambu or Ayah Ramin is the parent of their son who is named Ramin. Most of the data obtained from the Family Card, the age group that is still using this pattern is the adult group ranging from 46-100 years. However, it is possible for younger age groups to still use this pattern only for a few people.

\section{Runtah and Pulung Names}

This classification shows another peculiarity that is rarely used by the Baduy tribe, namely the names $\mathrm{R}$ vomit and Pulung. Vomiting means garbage and pulung means picking up/taking/maintaining it. Both names have negative connotations in Sundanese, because Runtah refers to rubbish / something that is discarded and unused. Pulung refers to something that is taken from another place and maintained. This naming is used in the Baduy tribe, initially as a repellent to reinforcements if the child is often sick. However, as the times evolved and the interaction of the Baduy tribe became wider, the two names were difficult to find.

Table. 3

\begin{tabular}{|c|c|c|c|}
\hline No. & Name of Children & $\begin{array}{c}\text { Parent Name } \\
\text { (Father/Mother) }\end{array}$ & $\begin{array}{c}\text { Children } \\
\text { Classification }\end{array}$ \\
\hline $\mathbf{4 6 .}$ & Runtah & Jaiman & F. 0-11 tahun \\
\hline $\mathbf{4 7 .}$ & Runtah & Talkimin & F. 12-25 tahun \\
\hline $\mathbf{4 8 .}$ & Arsih Munarsih & Runtah & F. 26-45 tahun \\
\hline $\mathbf{4 9 .}$ & Perdi & Runtah & M. 26-45 tahun \\
\hline $\mathbf{5 0 .}$ & Saidi & Runtah & M. 26-45 tahun \\
\hline $\mathbf{5 1 .}$ & Sanip & Runtah & M. 26-45 tahun \\
\hline $\mathbf{5 2 .}$ & Tura & Runtah & M. 26-45 tahun \\
\hline $\mathbf{5 3 .}$ & Armuda & Pulung & M. 0-11 tahun \\
\hline $\mathbf{5 4 .}$ & Sarpin & Pulung & M.11-25 tahun \\
\hline $\mathbf{5 5}$ & Cainah & Pulung Dayat & F. 0-11 tahun \\
\hline
\end{tabular}




\begin{tabular}{|l|l|l|l|}
\hline 56. & Sarah & Pulung Dayat & F. 12-25 tahun \\
\hline
\end{tabular}

Table 3 above shows that in the 1390 names collected, there were only two children named Runtah, five parents named Runtah and three parents named Pulung. Until this data were obtained, the children names of Pulung was not found. It can be assumed that there is wider knowledge in the Baduy community that the two names have experienced a shift in meaning. There are only two children who are still given the name Runtah. In addition, Runtah and Pulung are only used by their parents. The age category also shows that the child's generation rarely uses this name.

\section{Conclusion}

The Baduy tribe is still faithful in using the first syllable of father / mother for their child. The prefix variants Ar-, Ja-, Ra-, and Sa- are very dominant in the naming of the Baduy tribe. The patterns of the prefixes of the father's name is used in the name of a daughter is a characteristic that the father gives protection to his daughter. Meanwhile, the prefixes of the mother's name in boys is a sign that boys protect their mothers. Another uniqueness is the use of the names of male parents with the names Ayah and Ambu for female followed by the name of the first child, indicating that the first child is a representative figure of his existence as a father / mother in the eyes of the Baduy community.

Meanwhile, the names Pulung and Runtah were originally the names given to children who were often sickly. As the Baduy's social contact with the outside world is intense, the two names are rarely used because they connote the meaning of trash and things that are discarded.

\section{References}

[1] C. Sobarna, "Makna Nama: Cara Berpikir Masyarakat Sunda," in Makna Nama dalam Bahasa Nusantara: Sebuah Kajian Antropolinguistik, Bandung: Bumi Siliwangi, 1993.

[2] E. D. Lawson, "Personal Naming Systems," in Names And Naming, Oxford University Press, Ed. Oxford, 2016

[3] T. Ainiala, M. Saarelma, and P. Sjoblom, Names in Focus: An Introduction to Finnish Onomastics. SKS Finnish Literature Society, 2012.

[4] M. Saito, G. Trousdale, K. Gibson, U. Gut, and G. Kristoffersen, Oxford Handbooks in Linguistics Oxford Handbooks Online Oxford Handbooks in Linguistics Oxford Handbooks in Linguistics, no. August 2018. 2015.

[5] S. T. Widodo, "Konstruksi Nama Orang Jawa Studi Kasus Nama-Nama Modern Di Surakarta," Humaniora, vol. 25, no. 1, pp. 82-91, 2013.

[6] D. Kosasih, "Kosmologi Sistem Nama Diri (antroponim) Masyarakat Sunda: dalam Konstelasi Perubahan Struktur Sosial Budaya," Semin. Int. "Hari Bhs. Ibu,” no. 1974, pp. 1-7, 2010.

[7] C. E. Permana, Tata Ruang Masyarakat Baduy. Jakarta: Wedatama Widya Sasta, 2006.

[8] C. E. Permana, Kearifan Lokal Masyarakat Baduy dalam Mitigasi Bencana. Jakarta: Wedatama Widya Sastra, 2010.

[9] S. Danasasmita and A. Djatisunda, "Kehidupan Masyarakat Kanenes," Bandung, 1986.

[10] J. et. a. Hamidi, Demokrasi Lokal nurut Masyarakat Baduy. Malang: Nuswantara, 2015.

[11] J. W. Creswell, Research Design (Qualitative, quantitative, and Mixed Methods Approaches). Los Angeles, London, New Delhi, Singapore, and Washington DC: SAGE, 2014. 
[12] K. Sudaryat, Yayat Prawirasumantri, Abud Yudibrata, Tata Basa Sunda Kiwari. Bandung: Yrama Midya, 2013.

[13] T. F. Djajasudarma, G. Gunardi, and U. A. Darsa, Tata Bahasa Acuan Bahasa Sunda. Jakarta: Departemen Pendidikan dan Kebudayaan, 1994. 